\title{
Genetic diversity and forest reproductive material - from seed source selection to planting
}

\author{
Vladan Ivetić, Jovana \\ Devetaković, Marina Nonić, \\ Dragica Stanković, Mirjana \\ Šijačić-Nikolić
}

\begin{abstract}
How much of genetic diversity is desirable in mass production of forest reproductive material? How mass production of forest reproductive material reduces genetic diversity? Relation between genetic diversity and mass production of forest reproductive material is discussed in a holistic manner. In indus trial forest plantations, narrow genetic diversity is desirable and reproductive material is produced at clone level. On the other hand, in conservation forestry a wide genetic diversity is imperative. Beside management goals, a desirable level of genetic diversity is related to rotation cycle and ontogeny of tree species. Risks of failure are lower in short rotations of fast growing species. In production of slow growing species, managed in long rotations, the reduction of genetic diversity increases the risk of failure due to causes unknown or unexpected at the time of planting. This risk is additionally increased in cases of seed transfer and in conditions of climate change. Every step in production of forest reproductive material, from collection to nursery production, has an effect on genetic diversity mainly by directional selection and should be considered. This review revealed no consistent decrease of genetic diversity dur ing forest reproductive material production and planting.
\end{abstract}

Keywords: Genetic Diversity, Forest Reproductive Material, Seed Production, Seedling Production, Directional Selection

processes or anthropogenic influence. The highest pressure is on species with medium ecological amplitude, habitat fragmentation and shortened or absent gene flow, which is instead needed for the maintenance of high GD (Habel \& Schmitt 2012). In addition to habitat fragmentation, forest management, which selectively removes trees and their genes from the forest (dysgenic selection), may affect the gene pool of forests (Farwig et al. 2008, Schaberg et al. 2008, St Clair \& Howe 2011), usually lessening the number and frequency of rare alleles, thereby lowering the estimates of future genetic potential (Adams et al. 1998, Schaberg et al. 2004, Hawley et al. 2005).

Processes involved in the production of forest reproductive material (FRM, such as seed processing and nursery production) can change the composition and the ratio among individual families in seed lots, seedling stock and in the planted forest at the end. Large changes leads to reduction
Faculty of Forestry University of Belgrade, Kneza Višeslava 1, 11030 Belgrade (Serbia)

@ Jovana Devetaković (jovana.devetakovic@sfb.bg.ac.rs)

Received: Jan 28, 2015 - Accepted: Feb 09, 2016

Citation: Ivetić V, Devetaković J, Nonić M, Stanković D, Šijačić-Nikolić M (2016). Genetic diversity and forest reproductive material - from seed source selection to planting. iForest 9: 801-812. - doi: 10.3832/ifor1577-009 [online 2016-06-13]

Communicated by: Marco Borghetti of $G D$ and unpredictable genetic gain in breeding programs (St Clair \& Adams 1993). The risk of reduction of diversity during production of FRM can be as large as the risk during transfer between seed zones (Campbell \& Sorensen 1984). All processes relating to the production of FRM for artificial reforestation, as well as their interactions, must be well understood in order to maximize genetic gain and maintain GD (Edwards \& El-Kassaby 1996).

There is little evidence that artificial forest regeneration leads to a reduction of $G D$ at the stand level, regardless the seedlings were originated from natural stands, seed stands or seed orchards (Koski 2000). Maintaining GD during reforestation/afforestation increases the chance of natural regeneration of new forest (Larjavaara 2008). Restored populations can be used as future sources of FRM if are properly designed (Thomas et al. 2014).

Transfer of FRM during afforestation/reforestation has a great influence on GD by changing gene frequency or introducing genes where they were not present before. The traditional "free movement of germplasm" in Central Europe is a complicating factor when discussing GD (Koski 2000, Kremer 2007), resulting in a large number of plantations with untraceable origin. Transfer of native species for forest regeneration represent the "experiments in progress" (Hufford \& Mazer 2003) and should be monitored, from known origin of FRM to field success and adaptation to changing environment. 
This paper provides an overview on relation between GD and FRM in a holistic way: from source selection, transfer of FRM, seed processing and seedling production to reforestation/afforestation.

\section{Levels of genetic diversity}

Genetic diversity can be considered at different hierarchical levels: species, provenance (population), family and individual level. GD at lower hierarchical levels depends on factors that prevent panmixia or completely random mating between all individuals (Boyle et al. 1997).

\section{Species level}

Maintenance of interspecific diversity in afforestation reduces establishment risks, increases biodiversity and the ability of natural regeneration; the value of forest products can be increased or decreased but it always complicates forest management with different management procedures for different species (Larjavaara 2008). Therefore, the artificial restoration and establishment of forests is usually performed with a single species. To maximize profit, the foresters often plant exotic, fast-growing species in monocultures (Arbez 2001). Although number of species used for planting is increasing (Carnus et al. 2006), the most used species in 2012 at global level were from two genera: Pinus sp. (42\%) and Eucalyptus sp. (26\% - FSC 2012).

There are potential advantages to be gained by using carefully designed species mixtures in place of monocultures (Kelty 2006); in particular, a significant increase in productivity is expected based on projections, as compared with pure stands of the component species (Mason \& Connolly 2013).

Provenance (population) level

Forest tree species are highly heterozygous and contain a high portion of total genetic variation within populations (provenances), while the interpopulation component of variation rarely exceeds $5 \%$ (Leo- nardi \& Menozzi 1995, Paule et al. 1995, Larsen 1996). However, differences between provenances can be detected in seed (Kuser \& Ching 1981, Melzack \& Watts 1982, Šijačić-Nikolić et al. 2007, Rawat \& Bakshi 2011, Caliskan 2014), seedlings (Stihl \& Persson 1991, Varelides et al. 2001, Ivetić et al. 2005, Loha et al. 2006, Ivetić \& Škorić 2013), and patterns of spatial distribution can be observed as well (Ivetić et al. 2012). Variation between populations may be clinal or ecotypic and knowledge on pattern of variation is important in cases of FRM transfer.

\section{Family level}

The number of families (half-sib lines) in reforestation determines the degree of $G D$ and adaptibility of the new stand or plantation. This number depends on the seed source (seed stands or orchards), seed processing and nursery production. Since GD can be assessed by the effective population size (Ne - Wright 1931), some forestry authorities use this parameter for the acceptance of FRM. For public reforestation in British Columbia, the minimum $\mathrm{Ne}$ recorded for seed lots must be 10 (Stoehr et al. 2004), thus capturing $95 \%$ of the population GD (diversity = 1-1/2 Ne $-\mathrm{Nei} 1973$, Yanchuk 2001).

\section{Individual level}

Genetic diversity within individuals depends on outcrossing and gene dispersal efficiency. In genetically variable tree species it is likely that every seed produced has a different genotype and considerable variation among individuals can be generated in offspring from just only a few parents (Adams et al. 1992). Use of FRM from outcrossing maintains a wide GD, while diversity at individual level is more important in clonal forestry.

A distinction should be made when discussing the number of clones in seed orchards and in clonal forestry (Lindgren \& Prescher 2005). Therefore, in this section we will address to the number of clones or
Fig. 1 - Influence of breeding on genetic diversity.

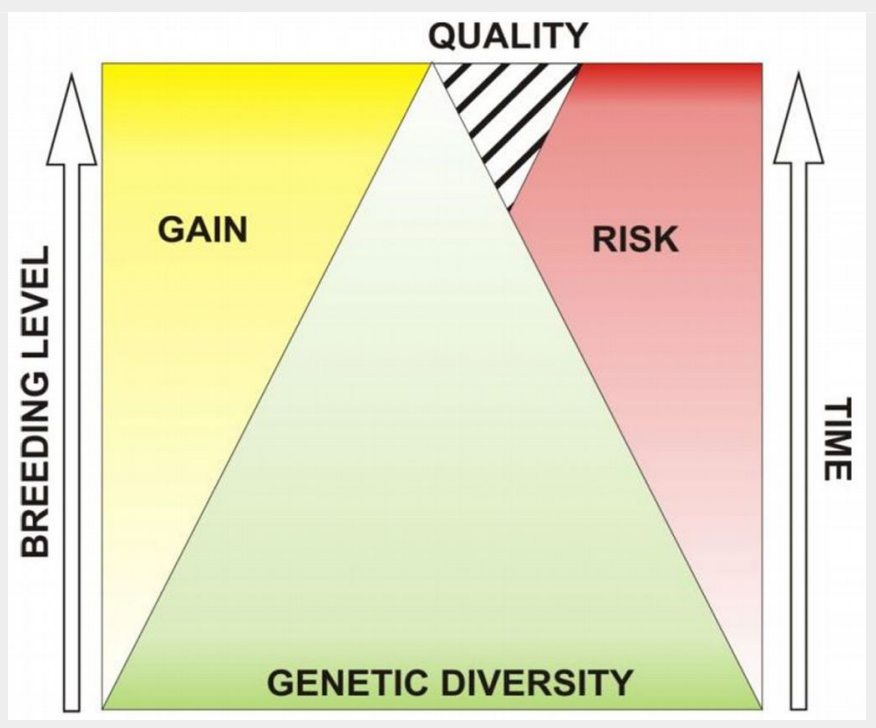

genotypes in plantations and deal with structure of seed orchards later.

There is no genetic variation within a monoclonal stand, thus diversity must be managed at the estate level (Griffin 2014). Combining clones allows resilience to environmental stress and yet still confer benefits of clonal forestry (Grossnickle \& Folk 2007). The number of clones or genotypes used in the establishment of plantations should balance genetic gain and loss of genetic diversity. This number with level of risk similar to forest established by seedlings, ranges from seven (Libby 1982) to 30 unrelated clones (Libby \& Ahuja 1993). More recent researches confirmed these recommendations (Bishir \& Roberds 1999, Yanchuk et al. 2006). For slow-growing species, a larger number of clones must be used.

\section{How much genetic diversity we need to maintain in the mass production of forest reproductive material?}

The answer to this question depends on the management objectives, rotation and the breeding level (Fig. 1). Reforestation for conservation purposes most often involves long rotations and requires a wide $G D$ because chances of hazardous situations rise with time (Fig. 1). Long-term trials showed that rare climatic events occurred every 10 or more years and that the prevalent reason of maladaptation was due to seed sources (Johnson et al. 2004). Commercial plantations have shorter rotations but narrow GD, as a result of long-term breeding programs, with short rotation coppice as an extreme example.

From the genetic point of view, we can distinguish three ways of artificial establishment of forests, and therefore the mass production of FRM for their needs. These are seedling forestry, family forestry and clonal forestry. In seedling forestry, the number of genotypes in new forests is equal to the number of planted seedlings. In family forestry, the number of genotypes is equal to the number of seedlings from controlled crossing (which is usually small) before vegetative multiplication. In clonal forestry, the number of genotypes is equal to the number of clones used for planting. Obviously, GD must be reduced in order to obtain genetic gain and because of that, it is very important to find the balance between these two objectives (GD and genetic gain) in forestry.

Each subsequent breeding level increases genetic gain but narrows genetic diversity. Increase of risk of failure follows the increase of rotation time. This risk is somewhat lower in case of production and use of good quality FRM.

\section{How mass production of forest reproductive material influence genetic diversity?}

Mass production of FRM is based on vegetative or generative reproduction. In this 
paper, we consider sexual reproduction with distinction between FRM from open and controlled pollination (crossing). Controlled crossing is limited in terms of quantity, and its use is often restricted to breeding programs. A combination of controlled crossing with mixed propagation can be used for the mass production of reproductive material, i.e., vegetative multiplication of young seedlings from full-sib families (Boyle et al. 1997). This method of regeneration is called "family forestry" (Nikles 1992, Muhs 1993). However, the most common reproductive material in forestry is produced by open crossing.

There are several methods for the production of improved reproductive material from open pollination. The mostly used are seed production areas (SPA) or seed stands (SS), parts of forest selected from natural stands or old plantations. The next level in tree breeding is seed orchards (SO) of trees without pedigree and, finally, clonal plantations of next generations from tested genotypes. Stands and orchards for the production of seeds from open pollination are suitable for use of the additive genetic variance (or general combining ability - Boyle et al. 1997). In this sense, the SO should ensure the improvement of the quality and quantity of seeds, in comparison to the SS (Sweet 1995), but it contains a limited number of genotypes. The level of improvement is assumed to rise from SS to clonal SO, but simultaneously a decline in genetic diversity may be expected. However, results of the studies rewieved in the following chapter do not support this assumption.

\section{Seed production}

\section{Seed source selection}

GD of seed lots is influenced by the size of the parent population, the balance in the parental reproductive success, the kinship of its members, and by the level of inbreeding (Funda et al. 2012). A large variability in fertility is observed between and within populations (Kang et al. 2003), among clones (El-Kassaby et al. 1989, Bilir et al. 2002, Nicodemus et al. 2009, Ertekin 2010, Li et al. 2011), and between years (Machanska et al. 2013). This variability was greater in the stands than in SO (Kang et al. 2003), in years of low yield (El-Kassaby et al. 1989) and in younger populations (Kang et al. 2003). In SO such variability is somewhat larger on the male than on the female side (Kang et al. 2003), opposite to what can be observed in natural population (Bilir et al. 2004). Some of the problems related to the effective population size and balance of parents in reproduction, can be solved with supplemental mass pollination (Franklin 1971, Sweet 1995) and assisted pollination (Mugnaini et al. 2004).

There are concerns about the effective number of parents in the SS and SO because only a portion of individuals con- tributes to the gametes pool and transmits its genes to the next generation (Hansen \& Kjaer 2006, Burgarella et al. 2007, Lai et al. 2010), thereby reducing the effective population size (El-Kassaby 1995). However, in plantations established from seed originating (or collected) from SO, there is no risk of further reduction of the effective population size in the next generation, because these plantations should not be used for seed collection (Stoehr et al. 2004).

Properly managed SS can be used as a source of high quality seeds for reforestation until genetically improved seed from SO becomes available. In most cases, the establishment of new forests with FRM originating from SS provides a level of GD similar to wild population from which they comes (Arbez 2001).

SS must consist of one or more groups of trees properly spaced and in sufficient numbers (OECD 2013b). Despite open pollination at the family level, there are deviations from the random mating in SS (King et al. 1984), which should be considered at seed collection. It is often necessary to perform genetic melioration in SS, which include seed trees selection, thinning and other activities that enhance productivity (Mataruga et al. 2010). Removing phenotypically inferior trees from SS improves the quality of seeds and seedlings (Sivakumar et al. 2011), but may reduce the GD of the next generation (Lyngdoh et al. 2013).

SO represent a link between tree breeding and afforestation (Kitzmiller 1990, ElKassaby 1992, Sweet 1995). The Organisation for Economic Co-operation and Development (OECD) scheme recognizes three types of SO: clonal, family and from material at the provenance level (OECD 2013b). The number of clones or genotypes that should be deployed into the SO is very important in terms of productivity and stand health. This number has to ensure the same level of heterozygosity expected in natural populations and greatly depends on the tree species. On the other hand, the genetic gain is increased through the decrease of the number of clones. In Sweden, Finland and Korea the usual number of clones in conifers SO ranges from 70 to 139 (Kang et al. 2001), while in the USA 24 clones (14-36) are usually considered for Pinus taeda L. and 42 (25-55) for Pinus elliottii Engelm (McKeand et al. 2003). For the establishment of SO in Finland the minimum number of clones is 30 (Koski 1980) and in Sweden the proposed number is 20 clones (Lindgren \& Prescher 2005). Concerning the number of clones to include in the establishment of SO, different recommendations are made by a number of authors: more than 20 clones (Johnson \& Lipow 2002), no more than 30 (Yanchuk et al. 2006) or 40 (Bishir \& Roberds 1999), between 30 to 40 (Roberds \& Bishir 1997), more than 40 (Koski 2000). However, not all clones should be represented with an equal number of ramets (Lindgren 1974, Lindgren \& Matheson 1986, Hodge \&
White 1993, Lindgren et al. 2009).

There is concern about the GD of seed lots from SO, because if a lower heterozygosity results from an increased level of inbreeding, we can expect a reduction of fitness (Booy et al. 2000), which may jeopardize the success of the establishment of new forests. However, the results of the reviewed studies are not conclusive (see Tab. 1). In all the eight studies reviewed here, isozyme markers were used to estimate the level of GD. There are more than one study only for Picea sitchensis and their results are similar.

The total number of alleles $(A)$ was higher in two SO of Picea sitchensis, compared to their natural populations (NP). In other three studies reporting $A$, allelic richness is reduced in SO. However, in all studies some alleles which were not observed in NP were recorded in SO.

The number of alleles per locus $(A n)$ and the percent of polymorphic loci $(P)$ in SO were equal to natural populations for Thuja plicata and Picea glauca x engelmanni; higher for Picea sitchensis (significantly) and Pseudotsuga menziesii, but lower for Picea glauca and Pinus banksiana.

The percent of polymorphic loci $(P)$ was equal in SO and NP of Thuja plicata and Picea glauca $x$ engelmanni; and higher for Picea sitchensis and Pseudotsuga menziesii. The polymorphism of loci in the SO was lower for Picea glauca and Pinus banksiana.

The expected heterozigosity $(\mathrm{He})$ was higher (not significantly) for Picea sitchensis and similar for other species.

The above results indicate that phenotypic selection at the early stage of breeding of highly polymorphic species does not significantly reduce genetic variability, likely due to the sampling of trees for plantation establishment from widely distributed natural populations (El-Kassaby \& Ritland 1996). These results are confirmed in more recent study for Picea glauca (Namroud et al. 2012), where single-nucleotide polymorphisms (SNPs) were used to assess the potential impact of artificial selection for height growth on the genetic diversity. The comparison of same-size control populations with different family selection intensities did not result in notable differences in standard genetic diversity estimates.

\section{Seed collection}

Seed collection is the critical stage in mass production of FRM for maintaining of $G D$. A large portion of the original GD in seed sources can be lost when seeds are collected from a small number and/or from inappropriate trees.

Two methods of collecting seeds are commonly applied (OECD 2013a). The first method involves the collection at SS level, not taking into account the parents' participation in seed lots. The second method is based on the collection of the same amount of seeds from each maternal plant (unit of collection), thereby better preserving GD. However, during collection, seeds 
Tab. 1 - Differences in the parameters of genetic diversity among natural populations (NP) and seed orchards (SO). (A): total number of alleles; $(\mathrm{Au})$ : number of alleles observed only in NP or SO; $(\mathrm{An})$ : number of alleles per locus; $(P)$ \% of polymorphic loci; $(\mathrm{He})$ : expected heterozygosity); $\left(^{*}\right)$ : first generation; $\left({ }^{* *}\right)$ : second generation; $(+)$ : arithmetic mean of replicates reported separately in the original study.

\begin{tabular}{|c|c|c|c|c|c|c|c|c|}
\hline \multirow{2}{*}{ Species } & \multirow{2}{*}{ Type } & \multicolumn{5}{|c|}{ Heterozygosity Parameters } & \multirow{2}{*}{ Markers } & \multirow{2}{*}{ Source } \\
\hline & & $A$ & $A u$ & $A n$ & $P$ & $\mathrm{He}$ & & \\
\hline \multirow[t]{2}{*}{ Pinus sylvestris L. } & NP & $34.7^{+}$ & - & - & - & $0.283^{+}$ & \multirow[t]{2}{*}{ Isozymes } & \multirow[t]{2}{*}{ Muona \& Harju (1989) } \\
\hline & so & $39.5^{+}$ & - & - & - & $0.266^{+}$ & & \\
\hline \multirow{2}{*}{$\begin{array}{l}\text { Thuja plicata } \\
\text { Donn ex D.Don }\end{array}$} & NP & - & - & 1.1 & 11.1 & 0.054 & \multirow[t]{2}{*}{ Isozymes } & \multirow[t]{2}{*}{ El-Kassaby (1992) } \\
\hline & so & - & 1 & 1.2 & 11.1 & 0.058 & & \\
\hline \multirow{4}{*}{$\begin{array}{l}\text { Picea sitchensis } \\
\text { (Bong.) Carr. }\end{array}$} & NP & - & 4 & 2.0 & 69.2 & 0.216 & \multirow[t]{2}{*}{ Isozymes } & \multirow[t]{2}{*}{ El-Kassaby (1992) } \\
\hline & so & - & 6 & 2.7 & 84.6 & 0.238 & & \\
\hline & NP & - & 3 & 1.82 & 66.9 & - & \multirow[t]{2}{*}{ Isozymes } & \multirow[t]{2}{*}{ Chaisurisri \& El-Kassaby (1994) } \\
\hline & so & - & 6 & 2.77 & 100 & - & & \\
\hline \multirow{3}{*}{$\begin{array}{l}\text { Pseudotsuga menziesii } \\
\text { (Mirb.) Franco }\end{array}$} & NP & - & 4 & 2.14 & 52.6 & 0.171 & \multirow[t]{3}{*}{ Isozymes } & \multirow[t]{3}{*}{ El-Kassaby \& Ritland (1996) } \\
\hline & $\mathrm{SO}^{*}$ & - & 2 & 2.28 & 62.5 & 0.172 & & \\
\hline & $\mathrm{SO}^{* *}$ & - & 1 & 2.25 & 56.3 & 0.163 & & \\
\hline \multirow[t]{2}{*}{ Picea glauca $x$ engelmanni } & NP & 46 & 7 & 2.7 & 64.7 & 0.210 & \multirow[t]{2}{*}{ Isozymes } & \multirow[t]{2}{*}{ Stoehr \& El-Kassaby (1997) } \\
\hline & so & 40 & 1 & 2.4 & 64.7 & 0.207 & & \\
\hline \multirow{2}{*}{$\begin{array}{l}\text { Picea glauca } \\
\text { (Moench.) Voss. }\end{array}$} & NP & 39 & 9 & 2.17 & 55.6 & 0.164 & \multirow[t]{2}{*}{ Isozymes } & \multirow[t]{4}{*}{ Godt et al. (2001) } \\
\hline & so & 31 & 1 & 1.72 & 50.0 & 0.157 & & \\
\hline \multirow[t]{2}{*}{ Pinus banksiana Lamb. } & NP & 55 & 12 & 2.04 & 59.3 & 0.114 & \multirow[t]{2}{*}{ Isozymes } & \\
\hline & so & 45 & 2 & 1.67 & 44.4 & 0.114 & & \\
\hline
\end{tabular}

are usually bulked in a seed lot at population or family level. In this regard, a seed lot represents the bulk of all parents that participate in seed production, though not all parents are equally represented. Once seeds of individual families (mother trees) are mixed, control over the participation of individual families to the seed lot is lost.

A uniform harvesting across the whole collecting area is recommended (Konnert \& Hosius 2010). The number of mother trees depends on the overall size of the area covered by seed collection, but the recommendations for this number vary depending on the source. The loss of genetic diversity in the next generation is inversely proportional to the number of sampled parents (Bila 2000); therefore, a smaller amount of seeds collected from many parent trees is more effective on GD maintenance than the opposite. For most purposes it is recommended to collect the same amount of seeds from at least 20 (Pacalaj et al. 2011) or 50 distant mother trees, so that each seed tree contributes with approximately $4 \%$ or $2 \%$, respectively, to the seed lot. In case of seed collection from 50 trees, the expected reduction in heterozygosity is $1 \%$ (Mataruga et al. 2013). However, it is safe to accept the recommendation that seed should not be collected from less than 40 trees, except in some cases (OECD 2013a). This number can be lower in natural distributed species or in pioneer species, and higher in dioecius species (Mataruga et al. 2013). Generally accepted rules have been developed for how many samples one should collect to capture at least $95 \%$ of genetic variation (measured as alleles) with the least effort (Thomas et al. 2014).

Mother (seed) trees should be carefully selected during collection and this is usually done by phenotypic selection. Pheno- typic selection successfully conserves genetic variation in natural populations and presents an easy and inexpensive way to provide material for further breeding (ElKassaby 1992).

Despite a sufficient number of properly selected seed trees is chosen for collection, the family ratio in the seed lot may be uneven. Number of viable seeds from different families may differ because of the unequal number of collected seeds, fruits or cones, different number of seeds in the fruits or cones and different viability due to the state of maturity, insect attacks, infections and maturation (Schmidt 2000).

Collecting seeds in non-mast years leads to a reduction of genetic diversity, as seeds from a small number of parents are included which generally are not representative of the population. Due to the large variation in the genetic structure of seed crops between years (Nikkanen \& Ruotsalainen 2000, Kulková 2007, Nielsen \& Hansen 2012), diversity can be preserved by mixing seeds collected in different years (Kang et al. 2005). Moreover, collecting seeds from trees of different age groups mimic natural regeneration and increases adaptive potential. However, cutting the youngest trees to implement a seed tree regeneration method leads to a reduction in the frequency of certain alleles; for this reason, collecting seeds from trees of different ages may preserve rare alleles to the next generation (Adams et al. 1998). Care should be taken to avoid unintentional selection of traits during seed harvest (e.g., systematically discarding small seed), and growth rate, timing of flowering and fruiting and harvesting time window should be also considered (Thomas et al. 2014).

\section{Seed processing}

Seed processing can lead to a decrease in
$G D$ by reducing the participation (or even the elimination) of some families from the initial seed lot. Most methods of seed processing are custom to average sized seed. Indeed, seeds closer to the average for any trait subject to processing, are less likely to be accidentally eliminated (Schmidt 2000). As seeds of different families may differ in size, weight, morphological and physiological characteristics, some families may be preferentially subject to selective pressures and can be eventually discarded from the final seed lot. Equal representation of all families in the seed lot is not possible in practice, unless each family is processed separately (Edwards \& El-Kassaby 1996, Schmidt 2000). Systematic elimination (directional selection) carries a higher risk for the reduction of GD in the seed lot, as certain types of seeds are discarded based on physiological and especially the physical properties of seeds, which are under strong genetic control of mother trees.

Unlike the systematic, random elimination has less impact on the genetic constitution of seed lot, because the seed probability to be eliminated does not depend on its physical or physiological traits. An example of random elimination is seed storage, when storability of large and small seeds or seeds from different families is the same (Schmidt 2000).

\section{Seed grading}

Seed grading is usually based on seed size and weight, and leads to rejecting a certain amount of small, but still viable seeds. This procedure can change the genetic constitution of the whole seed lot, discarding entire families with smaller seed size. However, even in the absence of seed grading a similar effect may occur, as the plants developed from small seeds are smaller and show a higher mortality rate (Campbell 
\& Sorensen 1984).

The size and weight of seeds are under strong parental genetic control (Annapurna et al. 2005, Carles et al. 2009, Singh \& Sofi 2011). In addition, seed size and weight also differ in relation to maturity (Campbell \& Sorensen 1984), position of reproductive structures, external conditions and year (Farmer 1997). As a consequence, grading based on seed size and weight entails at the same time a selection of other characteristics related to these.

The size and weight of seeds are positively associated with viability and germination parameters (Cicek \& Tilki 2007, Singh \& Sofi 2011). There is also a strong positive relationship with seedling attributes such as size and survival (St Clair \& Adams 1993, Cicek \& Tilki 2007, González-Rodríguez et al. 2011), but it weakens with time (Carles et al. 2009). However, although large seeds can provide rapid and successful germination and early seedlings growth, this is not necessarily related to the embryos genetic potential for growth (Schmidt 2000). Indeed, some results suggest that seed size is under moderate genetic control (i.e., seed size has a lesser impact on seedling attributes), while germination parameters are under strong genetic control (Chaisurisri et al. 1992, Annapurna et al. 2005). Lack of seed effect on seedling attributes was also observed (Chaisurisri et al. 1994). Therefore, what is obtained in terms of physiological quality by selecting only the most viable seeds may be lost in terms of genetic quality and diversity (Schmidt 2000). For this reason, Edwards \& El-Kassaby (1996) recommend mixing of sound and viable seeds from all size classes before storage or sowing.

\section{Seed storage and pre-sowing treatments}

Seed storability is under strong genotype influence and the preservation of viability during storage largely differs among families (Schmidt 2000). In this case, the risk of narrowing GD lies in the possibility that seeds with a relatively low vigor completely lose their viability over a long-storage period. In addition, seed dormancy has a strong genetic basis; therefore, seeds from different families may differently react to the pre-sowing treatments, and viable seeds can remain dormant during the germination period. However, seed treatment and stratification has been reported to have only minimal effects on the genetic structure of reproductive material (Konnert \& Hosius 2010).

\section{Germination}

Seed germination may strongly decrease GD of seed lots due to different germination capacity, speed and vigor among families and individual seeds, and may lead to either under- or overestimation of the effective population size of seed lots (Funda et al. 2012). In fact, the lack of germination of an individual family is actually positive as long as it is the result of genetic control, because a family of low genetic potential is eliminated from the nursery stock. However, if the absence of germination is due to seed processing, families with high genetic potential will not transfer genes into nursery stock, thereby changing the effective population size. The speed and vigor are important features because, in favorable nursery conditions, seedlings are immediately able to capture the available resources.

Seed germination parameters are under strong genetic control both in gymnosperm (El-Kassaby et al. 1993, Davidson et al. 1996, Carles et al. 2009) and angiosperm (Thomsen \& Kjaer 2002, Annapurna et al. 2005). This control is particularly pronounced in gymnosperm (Schmidt 2000), and can be explained by the maternal contribution which is dominant over the paternal (Edwards \& El-Kassaby 1996). However, it is very difficult to distinguish the genetic influence on germination from the influence of seed processing, in particular storage and dormancy.

Seed germination is an important parameter for seedlings production. This is well explained by Campbell \& Sorensen (1984): "In species with low germination capacity most of the loss occurs before germination, but in species with high germination capacity, the losses are associated with the rejection of the seedlings at the end of production. When the germination is weak, growing density in seedbed is low and most of the seedling exceed standard for rejection; when the seed germinates well, the density is high and larger number of seedlings does not satisfy standard criteria".

\section{Seedling production}

A high GD included in seed lots after collection may be contrasting with the uniformity desired for mass production of seedlings in the nursery. Indeed, seeds with uniform germination and seedlings with consistent growth are easier to be cultivated in the nursery. In addition, nursery operations are more effective when carried out in a homogenous environment.

A significant reduction in GD may take place in the nursery, depending on nursery conditions and production methods. Production of seedlings under environmental conditions much different from those at the seed collection site may cause directional selection at this stage or after planting (Campbell \& Sorensen 1984). Furthermore, it is often assumed that seedlings should be raised under climatic conditions similar to those at the future planting site, to avoid selective effects, but even if this seems optimal, it is not realistic (Konnert \& Hosius 2010).

Distinction should be made between production of bareroot and containerized seedlings. Risk of reduction in GD by directional selection is lower in production of bareroot seedlings with sowing seeds in the beds. However, selection pressure is stronger in bareroot nurseries compared to container nurseries, due to harsher field conditions during germination. Uniformity of growing conditions is a keystone for commercial nursery production. There are evidences that temporarily heterogeneous environmental conditions might promote a higher survival of heterozygote genotypes, while homozygosity could be favored in relatively homogeneous conditions (Finkeldey \& Ziehe 2004). However, the majority of the study did not confirm any reduced heterozygosity of seedlings grown under optimal, homogeneous environmental conditions (Tab. 2).

The production of containerized seedlings may also lead to a possible reduction of GD in the seedling stock. Indeed, more than one seeds are usually sown per cell and smaller seedlings are removed after germination. This results in an undesired directional selection favoring parents with less dormant and fast-germinating seeds, though their seedlings do not necessarily show better performances in the field. To this purpose, Edwards \& El-Kassaby (1996) recommend to sow one seed per cell or sowing of separated families, not the whole seed lots. Difference in seedling size among families has been well documented (Mathew \& Vasudeva 2005, Jacobs et al. 2006, Woeste et al. 2011, Devetaković et al. 2013). However, differences in family composition between the initial seed lot and the final seedling stock are often not large enough to justify the increased costs of producing seedlings from different families separately (St Clair \& Adams 1993).

Based on the literature examined, there are no evidences that nursery operations might reduce GD. In five reviewed studies, seedling stocks did not show significant differences in GD parameters as compared to their relative seed lots (Tab. 2). In addition, seedling stocks of Pseudotsuga menziesii var. menziesii used for artificial regeneration had a significantly higher level of GD compared to natural regeneration (Adams et al. 1998). Similar results have been reported for seedling stocks of Pinus contorta var. latifolia, with GD parameters similar to those of unmanaged stands, but higher compared to natural regeneration (Thomas et al. 1999). Furthermore, no reduction of GD through seedling production was observed in Pseudotsuga menziesii (Mirb.) Franco (St Clair \& Adams 1993, Konnert \& Ruetz 2006) and Fagus sylvatica $L$. (Konnert \& Ruetz 2003). In these studies, the similar GD found in the seedling stock as compared with the original population has been attributed to the favorable conditions of growth in the nursery, making the selection pressure in the nursery weaker than in nature. Contrastingly, significantly lower values of the GD parameters in the seedling stock compared to the parent seed stand have been reported only for Quercus ilex L. (Burgarella et al. 2007). The authors attributed this evidence to an inappropriate seed collection, which was lim- 
Tab. 2 - Differences in the parameters of genetic diversity between the seed lot (SL) and the seedling stock (SS). (A): total number of alleles; (An): number of alleles per locus; $(P)$ \% of polymorphic loci; (He): expected heterozygosity; (Ho): observed heterozygosity); (U): unmanaged; (NR): natural regeneration; (SOS): seed origin stand; (SO): seed orchard.

\begin{tabular}{|c|c|c|c|c|c|c|c|}
\hline \multirow{2}{*}{ Species } & \multirow{2}{*}{ Type } & \multicolumn{4}{|c|}{ Heterozygosity Parameters } & \multirow{2}{*}{ Markers } & \multirow{2}{*}{ Source } \\
\hline & & $A$ & $A n$ & $P$ & $\mathrm{He}$ & & \\
\hline \multirow{3}{*}{ Pinus contorta var. latifolia } & $\mathrm{U}^{1}$ & - & - & - & 0.44 & \multirow{3}{*}{ RAPD } & \multirow{3}{*}{ Thomas et al. (1999) } \\
\hline & $N R^{2}$ & - & - & - & 0.39 & & \\
\hline & SS & - & - & - & 0.43 & & \\
\hline \multirow[t]{2}{*}{ Picea glauca $x$ engelmanni } & SL & 38 & 2.2 & 70.6 & 0.219 & \multirow[t]{2}{*}{ Isozymes } & \multirow{2}{*}{$\begin{array}{l}\text { Stoehr \& El-Kassaby } \\
\text { (1997) }\end{array}$} \\
\hline & SS & 39 & 2.3 & 64.7 & 0.215 & & \\
\hline \multirow{2}{*}{$\begin{array}{l}\text { Pseudotsuga menziesii var. } \\
\text { menziesii }\end{array}$} & NR & - & - & 87 & 0.190 & \multirow[t]{2}{*}{ Isozymes } & \multirow[t]{2}{*}{ Adams et al. (1998) } \\
\hline & SS & - & - & 95.5 & 0.203 & & \\
\hline \multirow[t]{2}{*}{ Quercus ilex L. } & $\mathrm{SOS}^{3}$ & 10 & 8.79 & - & 0.653 & Microsatellites & \multirow[t]{2}{*}{ Burgarella et al. (2007) } \\
\hline & SS & 7 & 6.98 & - & 0.641 & - & \\
\hline \multirow[t]{4}{*}{ Quercus robur $\mathrm{L}$. } & $\mathrm{SO}^{4}$ & - & - & - & 0.29 & Isozymes & \multirow[t]{4}{*}{ Borovics et al. (2012) } \\
\hline & SS & - & - & - & 0.28 & & \\
\hline & SO & - & - & - & 0.75 & \multirow[t]{2}{*}{ Microsatellites } & \\
\hline & SS & - & - & - & 0.72 & & \\
\hline
\end{tabular}

ited to a small number of spatially close trees.

Finally, the reviewed studies also sug gested that seedling production in the nursery maintains the GD observed in the initial seed lot, regardless to species and production method (bareroot - St Clair \& Adams 1993, Konnert \& Ruetz 2003; or container - Konnert \& Ruetz 2003).

\section{Culling}

Grading and culling of seedlings is a routine procedure in nursery as integral part of lifting and packaging. Culling is usually based on height, diameter and physical damage. Culling based on physical damage does not represent a directional selection (the damage often occur by chance), while culling based on size can be directional, depending on the genetic control of height and diameter (Campbell \& Sorensen 1984). Genetic control of multiple traits related to to seedlings development has been reported (Wu \& Yeh 1997), though many nongenetic factors may affect seedling size.

Culling based on height and diameter partially discards inbred plants and other poor or abnormal genotypes, thus increasing the adaptability and growth capacity of the seedling stock. Such procedure does not constitute a directional selection, as inbred seedlings are usually inferior, susceptible to disease and often can not survive under field conditions. However, removing smaller plants from seedling stock can discard genotypes with possible faster growth at later stages. There are numerous examples that smaller seedlings in the nursery achieve a faster growth in the field (Rietveld \& Sambeek 1989, Thomson \& Schultz 1995, Jurásek et al. 2009). Careless selection of fast-growth families may represent the most important factor affecting GD (Davidson et al. 1996).

In this context, standards for seedlings culling should be determined by seed origin (seed stands, seed orchards and full-sib crossing) and nursery conditions (McClaren et al. 1994). In order to prevent further nar- rowing of GD, cultivation of all plants is recommended, including those that would be discarded based on the size. These can be grown one additional year in the nursery and used for planting on the same site (Jurásek et al. 2009).

\section{Reforestation (artificial regeneration)}

Reforestation activities largely depend on the goals, with distinction between forest regeneration and tree plantations. These goals must be a compromise between productive and non-productive (benefit) functions (e.g., biodiversity, landscape, environmental protection). Artificial regeneration of forests should replace the felled stand with a new, well-stocked and better quality stand (Skrøppa 1994), while in general tree plantations are defined as planted forests of commercially important species (Lindenmayer et al. 2003).

Artificial regeneration is the most obvious silvicultural practice resulting in possibly drastic changes of genetic structures not only in the planted stands, but also in the neighboring forests via gene flow (Finkeldey \& Ziehe 2004). The genetic structure and variation of artificially established forest stands may be conditioned at the species (monocultures or species mixtures) and individual (monoclonal or polyclonal) levels, depending on the initial seed lot and the seedling stock. Since GD of tree plantations was previously discussed, here we will deal with reforestation and artificial regeneration of forests only.

Distinction should be made between the establishment of new forests by direct sowing and planting of seedlings. From the genetic point of view, reforestation by direct sowing has a lower impact on GD as compared with planting seedlings (Mataruga et al. 2013). On the other hand, seedlings are by far the most used type of FRM in artificial regeneration.

Based on the literature analyzed in this review, differences between natural (including those from natural regeneration) and planted populations are not conclusive (Tab. 3). Seven out of 13 reviewed studies reported reduction of $G D$ after artificial regeneration and this reduction was significant in three cases: Picea glauca (Rajora 1999), Pinus brutia Ten. subsp. brutia (AlHawija et al. 2014) and Dalbergia sissoo (Pandey et al. 2004). The results previously obtained in Picea glauca by RAPD markers (Rajora 1999) were reassessed using microsatellites by Fageria \& Rajora (2014); a similar trend of reduction in GD was found, but the differences between progeny from phenotypic selection and natural regeneration were not significant (Tab. 3). The significant decrease of GD parameters from natural stands to plantations observed in Pinus brutia Ten. subsp. brutia (Al-Hawija et al. 2014) should be considered with care, since the small sample size analyzed and the origin of seeds used for plantation (obtained from older plantations, not from SO or natural SS). Pandey et al. (2004) found no variation at the Gdh-A locus in five plantations, while two to four alleles were found at the same locus in five natural populations. This complete fixation of Gdh-A gene locus in plantations was probably due to inappropriate seed collection (seed origin was unknown) from a small number of trees.

The above results suggest no significant negative impact of artificial regeneration per se on GD. Nonetheless, this impact is clearly influenced by the type of FRM and the level of GD captured in FRM.

\section{Transfer of forest reproductive material}

Although the transfer of FRM is not directly related to its production, knowledge of the future use can provide important guidance for mass production. The success of reforestation in the case of transfer of reproductive material is directly dependent on the ability of a population to adapt to the new environmental conditions. Previous work has mainly focused on pairing provenances or genotypes with sites 
Tab. 3 - Differences in the parameters of genetic diversity between initial population or natural population and new plantations. $(A)$ : total number of alleles; $(A n)$ : number of alleles per locus; $(P)$ \% of polymorphic loci; $(\mathrm{He})$ : expected heterozygosity; (Ho): observed heterozygosity); (+): Arithmetic mean of replicates separately reported in original study.

\begin{tabular}{|c|c|c|c|c|c|c|c|c|}
\hline \multirow{2}{*}{ Species } & \multirow{2}{*}{ Type } & \multicolumn{5}{|c|}{ Heterozygosity Parameters } & \multirow{2}{*}{ Markers } & \multirow{2}{*}{ Source } \\
\hline & & $A$ & $A n$ & $P$ & $\mathrm{He}$ & Ho & & \\
\hline \multirow[t]{7}{*}{ Pinus sylvestris L. } & Natural & - & - & - & $0.419^{+}$ & $0.359^{+}$ & Isozymes & Muona et al. (1987) \\
\hline & Plantation & - & - & - & $0.423^{+}$ & $0.408^{+}$ & & \\
\hline & Initial Krotoszyn & 77 & 3.08 & 92 & 0.254 & 0.254 & Isozymes & Kosinska et al. (2007) \\
\hline & Plantation Krotoszyn & 78 & 3.12 & 92 & 0.242 & 0.231 & & \\
\hline & Initial Gubin & 69 & 2.76 & 80 & 0.257 & 0.256 & & \\
\hline & Plantation Gubin 1975 & 74 & 2.96 & 96 & 0.234 & 0.233 & & \\
\hline & Plantation Gubin 1982 & 65 & 2.56 & 80 & 0.244 & 0.237 & & \\
\hline \multirow{8}{*}{$\begin{array}{l}\text { Pinus contorta } \\
\text { var. latifolia }\end{array}$} & Unmanaged & - & - & - & $0.44^{+}$ & - & RAPD & Thomas et al. (1999) \\
\hline & Natural regeneration & - & - & - & $0.39^{+}$ & - & & \\
\hline & Plantation & - & - & - & $0.43^{+}$ & - & & \\
\hline & Unmanaged & 12.2 & - & - & $0.73^{+}$ & $0.46^{+}$ & SSR & \\
\hline & Natural regeneration & 11.5 & - & - & $0.72^{+}$ & $0.47^{+}$ & & \\
\hline & Plantation & 11.5 & - & - & $0.74^{+}$ & $0.46^{+}$ & & \\
\hline & Natural regeneration & - & 1.83 & 32.6 & 0.160 & 0.137 & Isozymes & Macdonald et al. \\
\hline & Plantation & - & 1.83 & 35 & 0.149 & 0.138 & & $(2001)$ \\
\hline \multirow{2}{*}{$\begin{array}{l}\text { Pinus brutia Ten. } \\
\text { subsp. brutia }\end{array}$} & Natural & - & - & 83.7 & 0.248 & - & RAPD & Al-Hawija et al. (2014) \\
\hline & Plantation & - & - & 78.7 & 0.234 & - & & \\
\hline \multirow{2}{*}{ Pinus roxburghii Sarg. } & Natural & - & 5 & - & 0.52 & 0.5 & Microsatellites & Gauli et al. (2009) \\
\hline & Plantation & - & 4.93 & - & 0.52 & 0.5 & & \\
\hline \multirow{8}{*}{$\begin{array}{l}\text { Picea glauca } \\
\text { (Moench) Voss }\end{array}$} & Old natural & - & 1.89 & 88.7 & - & 0.381 & RAPD & Rajora 1999 \\
\hline & Natural regeneration & - & 1.84 & 83.8 & - & 0.349 & & \\
\hline & Plantation & - & 1.72 & 72.2 & - & 0.297 & & \\
\hline & $\begin{array}{l}\text { Progeny from phenotipic } \\
\text { selection }\end{array}$ & - & 1.67 & 66.5 & - & 0.259 & & \\
\hline & Natural old & 109 & 10.9 & - & 0.637 & 0.492 & Microsatellites & Fageria \& Rajora \\
\hline & Natural regeneration & 108 & 10.8 & - & 0.643 & 0.500 & & $(2014)$ \\
\hline & Plantation & 102 & 10.1 & - & 0.632 & 0.479 & & \\
\hline & $\begin{array}{l}\text { Progeny from phenotipic } \\
\text { selection }\end{array}$ & 100 & 10 & - & 0.634 & 0.788 & & \\
\hline \multirow[t]{5}{*}{ Picea abies } & Initial & - & 3 & - & 0.169 & 0.183 & Isozymes & Pacalaj et al. (2011) \\
\hline & Progeny from 10 & - & 2.95 & - & 0.190 & 0.189 & & \\
\hline & Progeny from 20 & - & 2.95 & - & 0.182 & 0.182 & & \\
\hline & Progeny from 30 & - & 3 & - & 0.181 & 0.184 & & \\
\hline & Progeny from 40 & - & 2.91 & - & 0.183 & 0.182 & & \\
\hline \multirow[t]{2}{*}{ Picea mariana } & Natural regeneration & - & 2.56 & 77.3 & 0.320 & 0.237 & Isozymes & Rajora \& Pluhar (2003) \\
\hline & Artificial regeneration & - & 2.51 & 72.7 & 0.315 & 0.230 & & \\
\hline \multirow{2}{*}{$\begin{array}{l}\text { Cupressus sempervirens L. } \\
\text { var. horizontalis }\end{array}$} & Natural & - & - & 77.8 & 0.244 & - & RAPD & Al-Hawija et al. (2014) \\
\hline & Plantation & - & - & 79.3 & 0.241 & - & & \\
\hline \multirow[t]{2}{*}{ Quercus ilex L. } & - & - & - & - & - & - & Microsatellites & Burgarella et al. (2007) \\
\hline & Plantation & 6 & 5.97 & - & 0.518 & - & & \\
\hline \multirow{3}{*}{$\begin{array}{l}\text { Araucaria angustifolia } \\
\text { (Bertol.) Kuntze }\end{array}$} & Nonmanaged & - & - & 82.0 & - & 0.26 & RAPD & Medri et al. (2003) \\
\hline & Managed & - & - & 72.5 & - & 0.26 & & \\
\hline & Progeny & - & - & 59.7 & - & 0.22 & & \\
\hline \multirow[t]{2}{*}{ Dalbergia sissoo Roxb. } & Natural & $3^{+}$ & - & - & 0.255 & - & Isozymes & Pandey et al. (2004) \\
\hline & Plantation & 1 & - & - & 0 & - & & \\
\hline
\end{tabular}

where they adapted well and where they can be well recovered. Transfer of reproductive material should be based on knowledge on planting site, species genetic diversity and biology (Ivetić et al. 2009). Transfer of reproductive materials contributes to gene flow, introducing new genes into local gene pools or changing the local frequencies of genes already existing in the local pool (Adams et al. 1992). Uncontrolled transfer and the use of FRM of unknown origin pose threats to the adaptation and/or the adaptive potential of tree plantations, and its consequences are not necessarily restricted to plantations (Finkeldey \& Ziehe 2004).
Provenance tests show that transferred bringing the need of redefining the conpopulations often perform as well as the cept of local gene pool and seed zones local provenances or better (Ivetić et al. (Bunnell \& Kremsater 2012). Forest tree 2005, Krakowski \& Stoehr 2009). Prove- populations planted today must face clinances from warmer climate grow faster mate challenges during this century (Wilthan the local populations, as long as they liams \& Dumroese 2013). In this context, are not transferred to a much different cli- there are three possible outcomes for formate (Schmidtling \& Myszewski 2004). This est tree populations in a rapidly changing may be due to the fact that plants from environment: persistence through migrawarmer climate grow longer in the fall than tion, persistence through adaptation in curin colder climates (Jayawickrama et al. rent locations and extirpation (Aitken et al. 1998) and this growth pattern is main- 2008).

tained in the new conditions. However, There is concern that local natural adapfavorable growth environments for spe- tation and migration of plants can not keep cific provenances or populations are cur- up pace with climate change. However, rently changing due to climate change, evolution of trees can take place in just a 
few generations or less than 200 years and, in some cases, even only one generation is needed for local adaptation (Skrøppa \& Kohmann 1997, Kremer 2007, Skrøppa et al. 2010). Adaptation of trees can be sup ported by appropriate transfer of FRM, taking into account the seasonal adaptation (Savolainen et al. 2007). Efficient implementation of assisted migration depends on clear guidelines for the transfer of reproductive material in light of climate change (Gray \& Hamann 2011). Populations expected to adapt to future climates are located lower in elevation and further south (St Clair \& Howe 2011); they should be mixed with local populations to favor adaptation to new conditions (St Clair \& Howe 2007). Transfer of FRM northward and/or to colder environment results, to some extent, in the maximum gain in height over local sources (Schmidtling \& Sluder 1995). However, transfer of FRM northward or at higher elevation increases the risk of failure due to sudden stress events. In this sense, nurserymen should collaborate with geneticists to identify genotypes resistant to extreme temperatures and water stress (Williams \& Dumroese 2013).

Beside the choice of the best suited FRM (in terms of origin, type, quality, planting site and goal-specific management), tracking the identity of the transferred material is necessary. Unfortunately, at the operational level, application of this theoretical model is often limited by the FRM available on the market. FRM producers (including seed collectors, seed processing stations, nurseries) tend to minimize the number of species, due to economic and management reasons. This emphasizes the need of a project specific planning period of at least five years to allow the production of appropriate FRM for the majority of species, from seed source selection based on transfer guidelines, to seedling production and planting. Additional attention should be payed in situations when a large amount of FRM is needed in short time, after the occurrence of catastrophic events (forest fire, wind or frost damage on large areas).

\section{Conclusion}

High genetic diversity is essential for the long-term survival of forests, providing the basis for future adaptation and resistance to stress and changing environment. $A$ high degree of $G D$ is also needed in the case of FRM transfer to long distances or different climates to ensure local adaptation of the transferred material.

Many steps in the mass production of FRM may potentially lead to a reduction of $G D$ in seedling stocks. Phenotype selection, transfer of FRM and breeding, are selective practices that favor specific genotypes. Seed processing and storage, as well as nursery conditions and operations, can also favor certain families and discard others. Furthermore, grading of seed and seedlings can result in unwanted directional selection of the FRM. However, based on the litarure analyzed in this review, no consistent decrease of genetic diversity has been observed during forest reproductive material production and planting.

The adoption of appropriate collection strategies can maximize the genetic diversity in seed lots, aimed to avoid population genetic bottlenecks and maintain the largest effective population size. Collecting seeds from trees of different ages, as well as the mixing of seeds collected in different years, may contribute to maintain GD. Mixing of various classes of seeds before sowing is recommended in cases of afforestation for conservation purposes. Seed collection, processing and seedling production at family level, followed by mixing of seed/seedling families before their use is the safest way to preserve genetic diversity, though this complicates production practices and unduly increases their costs.

Nursery procedures aimed at providing the greatest number of plants per unit of seed, the highest percentage of acceptable trees and the maximum survival of outplanted seedlings, may reduce the risk of narrowing GD. Selection pressure on seedlings tends to reduce when growing conditions are favorable, so that weaker genotypes, non-competitive in natural conditions, can develop into high-quality seedlings. Regarding seedlings production, culling undersized seedlings has the greatest impact in terms of reduction in GD of the FRM. Standards for culling, especially based on height, should be adjusted by taking into account lower hierarchical levels of $G D$ (provenance, population) and the final use of seedlings. Nursery production practices should provide a uniform planting material, with minimal need for culling.

Reforestation success relies on large local diversity, with a choice of appropriate species and proper transfer of FRM. The genetic diversity of the planting material is the result of previous operations carried out during its production. In this context, sowing seeds instead of planting seedlings reduces the risks of loss of GD as the result of directional selection during seed processing and seedling production. However, planting of seedlings is recommended, because it ensures a higher survival rate and a greater chance of success. High survival and high-density planting in reforestation programs promote natural selection in the new population.

\section{References}

Adams WT, Campbell RK, Kitzmiller JH (1992). Genetic considerations in reforestation. In: "Reforestation Practices in Southwestern Oregon and Northern California" (Hobbs SD, SD Tesch, PW Owston eds), Forest Research Laboratory, Oregon State University, Corvallis, OR, USA, pp. 284-308.

Adams WT, Zuo J, Shimizu JY, Tappeiner JC (1998). Impact of alternative regeneration methods on genetic diversity in coastal Douglas-fir. Forest Science 44: 390-396.
Aitken SN, Yeaman S, Holliday JA, Wang T, Curtis-McLane S (2008). Adaptation, migration or extirpation: climate change outcomes for tree populations. Evolutionary Applications 1: 95-111. - doi: 10.1111/j.1752-4571.2007.00013.x

Al-Hawija BN, Wagner V, Hensen I (2014). Genetic comparison between natural and planted populations of Pinus brutia and Cupressus sempervirens in Syria. Turkish Journal of Agriculture and Forestry 38: 267-280. - doi: 10.3906/tar-121124

Annapurna D, Rathore TS, Somashekhar PV (2005). Impact of clones in a clonal seed orchard on the variation of seed traits, germination and seedling growth in Santalum album $\mathrm{L}$. Silvae Genetica 54: 153-160.

Arbez M (2001). Ecological impacts of plantation forests on biodiversity and genetic diversity. In: Proceedings of the $7^{\text {th }}$ Annual EFI Conference "Ecological and socio-economic impacts of close-to-nature forestry and plantation forestry: a comparative analysis" (Green T ed). Lisbon (Portugal), Sep 2000. European Forest Institute, Joensuu, Finland, pp. 7-20.

Bila AD (2000). Fertility variation and its effects on gene diversity in forest tree populations. Ph.D. Thesis. Acta Universitatis Agriculturae Sueciae, Silvestria 166, Swedish University of Agricultural Sciences, Umea, Sweden, pp. 31.

Bilir N, Kang KS, Ozturk H (2002). Fertility variation and gene diversity in clonal seed orchards of Pinus brutia, Pinus nigra and Pinus sylvestris in Turkey. Silvae Genetica 51: 112-115.

Bilir N, Kang KS, Zang D, Lindgren D (2004). Fertility variation and status number between a base population and a seed orchard of Pinus brutia Ten. Silvae Genetica 53: 161-163.

Bishir J, Roberds JH (1999). The numbers of clones needed for managing risks in clonal forestry. Forest Genetics 6 (3): 149-155.

Booy G, Hendriks RJJ, Smulders MJM, Van Groenendael JM, Vosman B (2000). Genetic diversity and the survival of populations. Plant Biology 2 (4): 379-395. - doi: 10.1055/s-2000-5958 Borovics A, Cseke K, Molnár T (2012). Genetic consequences of utilization artificial populations in forestry. In: Proceedings of the Conference "Seed Orchards and Breeding Theory". Antalya (Turkey) 21-25 May 2012. Forestry Faculty of Suleyman Demirel University and International Union Forest Research Organization (IUFRO), Isparta, Turkey, pp. 67-71.

Boyle TJB, Cossalter C, Griffin AR (1997). Genetic resources for plantation forestry. In: "Management of soil, nutrients and water in tropical plantation forests" (Sadanandan Nambiar EK, Brown Alan G eds). ACIAR, Canberra, Australia, pp. 25-63.

Bunnell FL, Kremsater LL (2012). Actions to promote climate resilience in forests of British Columbia. Journal of Ecosystems and Management 13 (2): 1-10.

Burgarella C, Navascués $M$, Soto A, Lora A, Fici S (2007). Narrow genetic base in forest restoration with holm oak (Quercus ilex L.) in Sicily. Annals of Forest Science 64 (7): 757-763. - doi: 10.1051/forest:2007055

Caliskan S (2014). Germination and seedling growth of holm oak (Quercus ilex L.): effects of provenance, temperature, and radicle pruning. iForest - Biogeosciences and Forestry 7 (2): 103- 
109. - doi: 10.3832/iforo967-007

Campbell RK, Sorensen FC (1984). Genetic implications of nursery practices. In: "Forest Nursery Manual: Production of Bareroot Seedlings" (Duryea ML, Landis TD eds). Martinus Nijhoff/ Dr. W. Junk Publishers, The Hague/Boston/Lancaster, pp. 183-191.

Carles S, Lamhamedi MS, Beaulieu J, Stowe DC, Colas F, Margolis HA (2009). Genetic variation in seed size and germination patterns and their effect on white spruce seedling characteristics. Silvae Genetica 58 (4): 152-161.

Carnus JM, Parrotta J, Brockerhoff E, Arbez M, Jactel H, Kremer A, Lamb D, O'Hara K, Walters $B$ (2006). Planted forests and biodiversity. Journal of Forestry 104: 65-77. [online] URL: http:// www.ingentaconnect.com/content/saf/jof/200 6/00000104/00000002/art00005

Chaisurisri K, Edwards DGW, El-Kassaby YA (1992). Genetic control of seed size and germination in Sitka spruce. Silvae Genetica 41: 348355.

Chaisurisri K, Edwards DGW, El-Kassaby YA (1994). Effects of seed size on seedling attributes in Sitka spruce. New Forests 8: 81-87.

Chaisurisri K, El-Kassaby YA (1994). Genetic diversity in a seed production population vs. natural populations of Sitka Spruce. Biodiversity and Conservation 3 (6): 512-523. - doi: 10.1007/BFo0115157

Cicek E, Tilki F (2007). Seed size effects on germination, survival and seedling growth of Castanea sativa Mill. Journal of Biological Sciences 7: 438-441. - doi: 10.3923/jbs.2007.438.441

Davidson RH, Edwards DGW, Sziklai O, El-Kassaby YA (1996). Genetic variation in germination parameters among populations of pacific Silver fir. Silvae Genetica 45 (2-3): 165-171.

Devetaković J, Šiljačić-Nikolić M, Ivetić V (2013). Variability of morphometric characteristics of one-year seedlings of different half-sib European White Elm (Ulmus effusa Wild.) from the Great War Island. Biologica Nyssana 4 (1-2): 8792.

Edwards DGW, El-Kassaby YA (1996). The biology and management of coniferous forest seed: genetic perspectives. The Forestry Chronicle 72 (5): 481-484. - doi: 10.5558/tfc72481-5

El-Kassaby YA, Fashler AMK, Crown M (1989). Variation in fruitfulness in a Douglas-fir seed orchard and its effect on crop management decisions. Silvae Genetica 38 (01): 113-121.

El-Kassaby YA (1992). Domestication and genetic diversity: should we be concerned? The Forestry Chronicle 68 (6): 687-700. - doi: 10.5558/ tfc68687-6

El-Kassaby YA, Chaisurisri K, Edwards DGW, Taylor DW (1993). Genetic control of germination parameters of Douglas-fir, Sitka spruce, western redcedar, and yellow-cedar and its impact on container nursery production. In: Proceedings of the International Symposium of IUFRO Project Group P2.04-00 (Seed problems) “Dormancy and barriers to germination". Victoria (British Columbia, Canada) 23-26 Apr 1991. Victoria, BC, Canada, pp. 37-42.

El-Kassaby YA (1995). Evaluation of the treeimprovement delivery system: factors affecting genetic potential. Tree Physiology 15 (7-8): 545550. - doi: 10.1093/treephys/15.7-8.545

El-Kassaby YA, Ritland K (1996). Impact of selec- tion and breeding on the genetic diversity in Douglas-fir. Biodiversity and Conservation 5 (6): 795-813. - doi: 10.1007/BFoo051787

Ertekin M (2010). Clone fertility and genetic diversity in a Black pine seed orchard. Silvae Genetica 59 (4): 145-150.

Fageria MS, Rajora OP (2014). Effects of silvicultural practices on genetic diversity and population structure of white spruce in Saskatchewan. Tree Genetics and Genomes 10 (2): 287296. - doi: 10.1007/s11295-013-0682-0

Farmer RE (1997). Seed ecophysiology of temperate and boreal zone forest trees. St. Lucie Press, Delray Beach, FL, USA, pp. 272.

Farwig N, Braun C, Boöhning-Gaese K (2008). Human disturbance reduces genetic diversity of an endangered tropical tree, Prunus africana (Rosaceae). Conservation Genetics 9: 317-326. doi: 10.1007/s10592-007-9343-x

Finkeldey R, Ziehe M (2004). Genetic implications of silvicultural regimes. Forest Ecology and Management 197: 231-244. - doi: 10.1016/j. forec0.2004.05.036

Franklin EC (1971) Pollen management in southern seed orchards. In: Proceedings of the " $11^{\text {th }}$ Southern Forestry Tree Improvement Conference". Atlanta (GA, USA) Jun 1971. The North Carolina State University, Industry Cooperative Tree Improvement Program, Raleigh, NC, USA, pp. 218-223.

Funda T, Lstiburek M, Klápšte J, El-Kassaby YA (2012). Optimization of genetic gain and diversity in seed orchard crops considering variation in seed germination, Scandinavian Journal of Forest Research 27 (8): 787-793.

Gauli A, Gailing O, Stefenon VM, Finkeldey R (2009). Genetic similiarity of natural populations and plantations of Pinus roxburghii Sarg. in Nepal. Annals of Forest Science 66 (7): 703703. - doi: 10.1051/forest/2009053

Godt MJW, Hamrick JL, Burke MA, Williams JH (2001). Comparisons of genetic diversity in white spruce (Picea glauca) and jack pine (Pinus banksiana) seed orchards with natural populations. Canadian Journal of Forest Research 31 (6): 943-949. - doi: 10.1139/x01-024

González-Rodríguez V, Villar R, Navarro-Cerrillo RM (2011). Maternal influences on seed mass effect and initial seedling growth in four Quercus species. Acta Oecologica 37 (1): 1-9. - doi: 10.1016/j.actao.2010.10.006

Gray LK, Hamann A (2011). Strategies for reforestation under uncertain future climates: guidelines for Alberta, Canada. PLoS ONE 6 (8): e22977. - doi: 10.1371/journal.pone.0022977

Griffin AR (2014). Clones or improved seedlings of Eucalyptus? Not a simple choice. International Forestry Review 16 (2): 216-224. - doi: $10.1505 / 146554814811724793$

Grossnickle SC, Folk RS (2007). Field performance potential of a somatic interior spruce seedlot. New Forests 34 (1): 51-72. - doi: 10.1007/ s11056-006-9037-0

Habel JC, Schmitt T (2012). The burden of genetic diversity. Biological Conservation 147: 270274. - doi: 10.1016/j.biocon.2011.11.028

Hansen OK, Kjaer ED (2006). Paternity analysis with microsatellites in a Danish Abies nordmanniana clonal seed orchard reveals dysfunctions. Canadian Journal of Forest Research 36 (4): 1054-1058. - doi: 10.1139/x05-299
Hawley GJ, Schaberg PG, DeHayes DH, Brissette JC (2005). Silviculture alters the genetic structure of an eastern hemlock forest in Maine, USA. Canadian Journal of Forest Research 35: 143-150. - doi: 10.1139/x04-148

Hodge GR, White TL (1993). Advanced-generation wind-pollination seed orchard design. New Forests 7: 213-236. - doi: 10.1007/BFo0127387 Hufford K, Mazer SJ (2003). Plant ecotypes: genetic differentiation in the age of ecological restoration. Trends in Ecology and Evolution 18: 147-155. - doi: 10.1016/S0169-5347(03)00002-8

FSC (2012). Strategic review on the future of forest plantation. A12-06869, INDUFOR, Helsinki, Finland, pp. 121.

Isajev V, Ivetić V, Lučić A, Rakonjac Lj (2009). Gene pool conservation and tree improvement in Serbia. Genetika 41 (3): 309 -327.

Ivetić V, Isajev V, Šijačić-Nikolić M (2005). Results of fourtheen year's old Norway spruce provenance test in Serbia. In: Proceedings of the Symposium "Forest and Sustainable Development”. Brasov (Romania) Sep 2005. Editura Universitatii Transilvania, Brasov, Romania, pp. 65-71.

Ivetić V, Isajev V, Perović $M$, Novaković $M$ (2009). Izbor provenijencija i transfer semena crnog jasena na osnovu ekoloških karakteristika [Selection of provenances and seed transfer of manna ash based on ecological characteristics]. Šumarstvo LXI (1-2): 143-154. [in Serbian]

Ivetić V, Isajev V, Nikolić A, Krstić M, Ristić D, Kostadinović M (2012). Delineation of beech provenance regions in Serbia by spatial analysis of genetic diversity. Genetika 44 (1): 101-108. doi: 10.2298/GENSR1201101l

Ivetić V, Škorić M (2013). The impact of seeds provenance and nursery production method on Austrian pine (Pinus nigra Arnold) seedlings quality. Annals of Forest Research 56 (2): 297305.

Jacobs DF, Woeste KE, Wilson BC, McKenna JR (2006). Stock quality of black walnut (Juglans nigra) seedlings as affected by half-sib seed source and nursery sowing density. Acta Horticulturae 705: 375-381.

Jayawickrama KJS, McKeand SE, Jett JB (1998). Phenological variation in height and diameter growth in provenances and families of loblolly pine. New Forests 16 (1): 11-25. - doi: 10.1023/A: 1016527317326

Johnson R, Lipow S (2002). Compatibility of breeding for increased wood production and long term sustainability: the genetic variation of seed orchard seed and associated risks. In: Proceedings of the "Wood compatibility initiative Workshop, No. 18" (Johnson A, Haynes R, Monserud R eds). Stevenson (OR, USA) 4-7 Dec 2001. General Technical Report PNW-GTR-563, Pacific Northwest Research Station, USDA Forest Service, Portand, OR, USA, pp. 169-179. [online] URL: http://www.fs.fed.us/pnw/pubs/ gtr563/gtr563a.pdf

Johnson G, Sorensen FC, St Clair JB, Cronn RC (2004). Pacific northwest forest tree seed zones: a template for native plants?. Native Plants Journal 5 (2): 131-140. - doi: 10.2979/NPJ. 2004.5.2.131

Jurásek A, Leugner J, Martincová J (2009). Effect of initial height of seedlings on the growth of 
planting material of Norway spruce (Picea abies [L. ] Karst.) in mountain conditions. Journal of Forest Science 55: 112-118.

Kang KS, Harju AM, Lindgren D, Nikkanen T, Almkvist C, Suh GU (2001). Variation in effective number of clones in seed orchards. New Forests 21: 17-33. - doi: 10.1023/A:1010785222169

Kang KS, Bila AD, Harju AM, Lindgren D (2003). Estimation of fertility variation in forest tree populations. Forestry 76: 329-344. - doi: 10.1093 /forestry/76.3.329

Kang KS, L-Kassaby E YA, Chung MS, Kim CS, Kang YJ, Kang BS (2005). Fertility variation and effective number in a clonal seed orchard of Cryptomeria japonica. Silvae Genetica 54: 104107.

Kelty MJ (2006). The role of species mixtures in plantation forestry. Forest Ecology and Management 233: 195-204. - doi: 10.1016/j.foreco.20 06.05.011

King JN, Dancik BP, Dhir NK (1984). Genetic structure and mating system of white spruce Picea glauca in a seed production area. Canadian Journal of Forest Research 14(5): 639-643. - doi: 10.1139/x84-115

Kitzmiller JH (1990). Managing genetic diversity in a tree improvement program. Forest Ecology and Management 35: 131-149. - doi: 10.1016/03 78-1127(90)90237-6

Konnert M, Hosius B (2010). Contribution of forest genetics for a sustainable forest management. Forstarchiv 4: 170-174.

Konnert M, Ruetz W (2003). Influence of nursery practices on the genetic structure of beech Fagus sylvatica L. seedling populations. Forest Ecology and Management 184 (1/3): 193-200. doi: 10.1016/S0378-1127(03)00206-8

Konnert M, Ruetz WF (2006). Genetic aspects of artificial regeneration of Douglas-fir (Pseudotsuga menziesii) in Bavaria. European Journal of Forest Research 125: 261-270. - doi: 10.1007/s10 342-006-0116-8

Kosinska J, Lewandowski A, Chalupka W (2007). Genetic variability of Scots pine maternal populations and their progenies. Silva Fennica 41 (1): 5-12. - doi: 10.14214/sf.304

Koski V (1980). Minimivaatimukset männyn siemenviljelyksille Suomessa [Minimum requirements for seed orchards of Scots Pine in Finland]. Silva Fennica 14: 136-149. [in Finnish] doi: 10.14214/sf.a15017

Koski V (2000). A note on genetic diversity in natural populations and cultivated stands of Scots pine Pinus sylvestris L. Investigacion Agraria, Sistemas y Recursos Forestales (Fuera de Serie 1): 89-95.

Krakowski K, Stoehr M (2009). Coastal Douglasfir provenance variation: patterns and predictions for British Columbia seed transfer. Annals of Forest Science 66 (8): 811-811. - doi: 10.1051/ forest/2009069

Kremer D (2007). How well can existing forests withstand climate change? In: "Climate change and forest genetic diversity: Implications for sustainable forest management in Europe" (Koskela J, Buck A, Teissier du Cros E eds). Biodiversity International, Rome, Italy, pp. 43-52.

Kulková L (2007). Effective population size estimation of a Larix decidua L. seed orchard. Lesn. Cas. Forestry Journal 53 (1): 25-32.

Kuser JE, Ching KK (1981). Provenance variation in seed weight, cotyledon number, and growth rate of western hemlock seedlings. Forest Science 26: 463-470.

Lai BS, Funda T, Liewlaksaneeyanawin C, Klápšte J, Van Niejenhuis A, Cook C, Stoehr MU, Woods J, El-Kassaby YA (2010). Pollination dynamics in a Douglas-fir seed orchard as revealed by pedigree reconstruction. Annals of Forest Science 67 (8): 808. - doi: 10.1051/forest/2010044

Larjavaara $M$ (2008). A review on benefits and disadvantages of tree diversity. The Open Forest Science Journal 1: 24-26. - doi: 10.2174/1874 398600801010024

Larsen AB (1996). Genetic structure of populations of beech (Fagus sylvatica L.) in Denmark. Scandinavian Journal of Forest Research 11 (3): 220-232. - doi: 10.1080/02827589609382931 Leonardi S, Menozzi P (1995). Genetic variability of Fagus sylvatica L. in Italy: the role of postglacial recolonization. Heredity 75: 35-44. - doi: 10.1038/hdy.1995.101

Li W, Wang X, Li Y (2011). Stability in and correlation between factors influencing genetic quality of seed lots in seed orchard of Pinus tabuliformis Carr. over a 12-year span. PLoS ONE 6(8): e23544. - doi: 10.1371/journal.pone.0023544 Libby WJ (1982). What is a safe number of clones per plantation? In: "Resistance to diseases and pests in forest trees" (Heybroek HM, Stephen $\mathrm{BR}$, von Weissenberg K eds). Purdoc, Wageningen, The Netherlands, pp. 342-360.

Libby WJ, Ahuja JR (1993). Clonal forestry. In: "Clonal Forestry II: Conservation and Application” (Ahuja JR, Libby WJ E eds), Springer-Verlag, Berlin, Germany, vol. 2, pp. 1-8.

Lindenmayer D, Hobbs R, Salt D (2003). Plantation forests and biodiversity conservation. Australian Forestry 66: 62-66. - doi: 10.1080/000491 58.2003.10674891

Lindgren D (1974). Breeding theory and progeny testing. In: Proceedings of the IUFRO Joint Meeting of Working Parties on Population and Ecological Genetics "Aspects of Suitable Number of Clones in a Seed Orchard". The Royal College of Forestry, Stockholm, Sweden, pp. 293-305.

Lindgren D, Matheson AC (1986). An algorithm for increasing the genetic quality of seed from seed orchards by using the better clones in higher proportions. Silvae Genetica 35: 173-177. Lindgren D, Prescher F (2005). Optimal clone number for seed orchards with tested clones. Silvae Genetica 54: 80-92.

Lindgren D, Danusevicius D, Rosvall O (2009). Unequal deployment of clones to seed orchards by considering genetic gain, relatedness and gene diversity. Forestry 82 (1): 17-28. - doi: 10.1093/forestry/cpno33

Loha A, Tigabu M, Teketay D, Lundkvist K, Fries A (2006). Provenance variation in seed morphometric traits, germination, and seedling growth of Cordia africana Lam. New Forests 32 (1): 71-86. - doi: 10.1007/s11056-005-3872-2

Lyngdoh N, Joshi G, Ravikanth G, Vasudeva R, Shaanker RU (2013). Changes in genetic diversity parameters in unimproved and improved populations of teak (Tectona grandis L.f.) in Karnataka state, India. Journal of Genetics 92 (1): 141-145. - doi: 10.1007/s12041-013-0226-2

Macdonald SE, Thomas BR, Cherniawsky DM, Purdy BG (2001). Managing genetic resources of lodgepole pine in west-central Alberta: patterns of isozyme variation in natural populations and effects of forest management. Forest Ecology and Management 152: 45-58. - doi: 10.1016/S0378-1127(00)00616-2

Machanska J, Bajcar V, Longauer R, Gömöry D (2013). Effective population size estimation in seed orchards: a case study of Pinus nigra Arn. and Fraxinus excelsior L. / F. angustifolia Vahl. Genetika 45 (2): 575-588. - doi: 10.2298/GENSR $1302575 \mathrm{M}$

Mason WL, Connolly T (2013). Mixtures with spruce species can be more productive than monocultures: evidence from the Gisburn experiment in Britain. Forestry 87 (2): 209-217. doi: 10.1093/forestry/cpto42

Mataruga M, Daničić V, Cvjetković B (2010). Teorijske osnove značaja sprov odenja genetskih melioracija u funkciji uredenja sjemenskih sastojina [Theoretical basis of the importance of the implementation of genetic melioration in the function of seed stand management]. Šumarstvo 62 (3-4): 101-110. [in Serbian]

Mataruga M, Isajev V, Orlović S (2013). Šumski genetički resursi [Forest genetic resources]. University book, Faculty of Forestry, University in Banja Luka, Bosnia and Herzegovina, pp. 399. [in Serbian]

Mathew J, Vasudeva R (2005). Variation of seedling vigour among half-sib families of teak (Tectona grandis). Journal of Tropical Forest Science 17 (1): 170-172.

McClaren EL, Krasowki MJ, Hawkins CDB (1994). Summer plant culling criteria of interior spruce: keeping the bad and throwing the good? In: Proceedings of the Meeting "Forest and Conservation Nursery Associations" (Landis TD, Dumroese RK eds). Williamsburg (VA, USA) 1114 Jul 1994. Gen. Tech. Rep. RM-GTR-257, Rocky Mountain Forest and Range Experiment Station, USDA Forest Service, Fort Collins, CO, USA, pp. 116-129.

McKeand S, Mullin T J, Byram T, White T (2003). Deployment of genetically-improved loblolly and slash pines in the south. Journal of Forestry 101 (3): 32-37.

Medri C, Ruas PM, Higa AR, Murakami M, De Fatima Raus C (2003). Effects of forest management on the genetic diversity in a population of Araucaria angustifolia (Bert.) O. Kuntze. Silvae Genetica 52: 202-205.

Melzack RN, Watts D (1982). Variations in seed weight, germination, and seedling vigour in the yew (Taxus baccata L.) in England. Journal of Biogeography 9 (1): 55-63. - doi: $10.2307 / 28447$ 30

Mugnaini S, Nepi M, Cresti L, Piotto B, Pacini E (2004). Artificially induced male competition to produce seeds for bioremediation purposes. In: Proceedings of the IUFRO \$3.02.00 Meeting "Nursery production and stand establishment of broadleaves to promote sustainable forest management" (Ciccarese L ed). Rome (Italy) 710 May 2001. APAT, Rome, Italy, pp. 97-100.

Muhs HJ (1993). Policies, regulations, and laws affecting clonal forestry. In: "Clonal forestry. Vol. 2. Conservation and application" (Ahuja MR, Libby WJ eds). Springer-Verlag, Berlin, Heidelberg, Germany, pp. 215-227.

Muona O, Harju A (1989). Effective population sizes, mating system and genetic variability in 
Scots pine natural populations and seed orchards. Silvae Genetica 38: 221-228.

Muona O, Yazdani R, Rudin D (1987). Genetic change between life stages in Pinus sylvestris: allozyme variation in seeds and planted seeldings. Silvae Genetica 35: 39-42.

Namroud M, Bousquet J, Doerksen T, Beaulieu J (2012). Scanning SNPs from a large set of expressed genes to assess the impact of artificial selection on the undomesticated genetic diversity of white spruce. Evolutionary Applications 5 (6): 641-656. - doi: 10.1111/j.1752-4571.2012.002 42.x

Nei M (1973). Analysis of gene diversity in subdivided populations. PNAS 70: 3321-3323. - doi: 10.1073/pnas.70.12.3321

Nicodemus A, Varghese $M$, Nagarajan B, Lindgren D (2009). Annual fertility variation in clonal seed orchards of teak (Tectona grandis L.f.) and its impact on seed crop. Silvae Genetica 58 (1-2): 85-93.

Nielsen UB, Hansen OK (2012). Genetic worth and diversity across 18 years in a Nordmann fir clonal seed orchard. Annals of Forest Science 69 (1): 69-80. - doi: 10.1007/s13595-011-0159-y

Nikkanen T, Ruotsalainen S (2000). Variation in flowering abundance and its impact on the genetic diversity of the seed crop in a Norway spruce seed orchard. Silva Fennica 34 (3): 205222. - doi: $10.14214 /$ sf.626

Nikles DG (1992). Influence of developments in breeding, propagation, molecular markers, gene transfer and other new technologies on genetic improvement strategies for forest trees in commercial plantation projects. In: Proceedings of the IUFRO Meeting "Mass Production Technology for Genetically Improved Fast Growing Forest Tree Species". AFOCEL (Bordeaux, France) 14-18 Sep 1992. Association Foret-Cellulose, Paris, France, pp. 137-150.

OECD (2013a). OECD guidelines on the production of forest reproductive materials. Organization for Economic Cooperation and Development Trade and Agriculture Directorate, Paris, France, pp. 24.

OECD (2013b). Rules and regulations of the OECD forest seed and plant scheme. Organization for Economic Cooperation and Development Trade and Agriculture Directorate, Paris, France, pp. 24.

Pacalaj M, Gömöry D, Longauer R (2011). Modelling the effects of natural and artificial regeneration on genetic structure. 1. Pure spruce stand. Lesn. Cas. Forestry Journal 57 (2): 96-112. Pandey M, Gailing O, Leinemann L, Finkeldey R (2004). Molecular markers provide evidence for long-distance planting material transfer during plantation establishment of Dalbergia sissoo Roxb. in Nepal. Annals of Forest Science 61: 603-606. - doi: 10.1051/forest:2004056

Paule L, Gömöry D, Vyšný J (1995). Genetic diversity and differentiation of beech populations in eastern Europe. In: "Genetic and Silviculture of Beech" (Madsen SF ed). Forskningserien 11, Forskningscentret for Skov \& Landskab, Denmark, pp. 159-167.

Rajora OP (1999). Genetic biodiversity impacts of silvicultural practices and phenotypic selection in white spruce. Theoretical and Applied Genetics 99 (6): 954-961. - doi: 10.1007/s00122 0051402
Rajora OP, Pluhar SA (2003). Genetic diversity impacts of forest fires, forest harvesting, and alternative reforestation practices in black spruce (Picea mariana). Theoretical and Applied Genetics 106: 1203-1212.

Rawat K, Bakshi M (2011). Provenance variation in cone, seed and seedling characteristics in natural populations of Pinus wallichiana A.B. Jacks (blue pine) in India. Annals of Forest Research 54 (1): 39-55.

Rietveld WJ, Sambeek JW (1989). Relating black walnut planting stock to field performance. In: Proceedings of the " 7 th Central Hardwood Forest Conference" (Rink G, Budelsky CA eds). Gen. Tech. Rep. NC-132, North Central Forest Experiment Station, USDA Forest Service, St. Paul, MN, USA, pp. 162-169.

Roberds JH, Bishir J (1997). Risk analysis in clonal forestry. Canadian Journal of Forest Research 27: 425-432. - doi: 10.1139/x96-202

Savolainen O, Bokma F, Knürr T, Kärkkäinen K, Pyhäjärvi T, Wachowiak W (2007). Adaptation of forest trees to climate change. In: "Climate change and forest genetic diversity: Implications for sustainable forest management in Europe" (Koskela J, Buck A, Teissier du Cros E eds). Bioversity International, Rome, Italy, pp. 19-30.

Schaberg PG, Hawley GJ, DeHayes DH, Nijensohn SE (2004). Silvicultural management and the manipulation of rare alleles. In: "Silviculture and the conservation of genetic resources for sustainable forest management" (Beaulieu J ed). Report LAU-X-128, Natural Resources Canada, Canadian Forest Service, Sainte-Foy, Quebec, Canada, pp. 67-74. [online] URL: http:// www.researchgate.net/publication/282357840 Schaberg PG, Dehayes DH, Hawley GJ, Nijensohn SE (2008). Anthropogenic alterations of genetic diversity within three populations: implications for forest ecosystem resilience. Forest Ecology and Management 256 (5): 855-862. doi: $10.1016 /$ j.foreco.2008.06.038

Schmidt LH (2000). Guide to handling of tropical and subtropical forest seed. Danida Forest Seed Centre, Krogerupvej-21, Denmark, pp. 532. Schmidtling RC, Sluder E (1995). Genecology and seed transfer in longleaf pine. In: Proceedings of the " $23^{\text {rd }}$ Southern Forest Tree Improvement Conference". Asheville (NC, USA) 20-22 Jun 1995. Southern Forest Tree Improvement Committee, Raleigh, NC, USA, pp. 78-85.

Schmidtling RC, Myszewski JH (2004). Effect of large-scale movement of loblolly pine seed on genetiv integrity of the species in its natural range. In: "Silviculture and the conservation of genetic resources for sustainable forest management" (Beaulieu J ed). Report LAU-X-128, Natural Resources Canada, Canadian Forest Service, Sainte-Foy, Quebec, Canada, pp. 43-48. [online] URL: http://www.researchgate.net/pu blication/282357840

Šijačić-Nikolić $M$, Ivetić $V$, Knežević R, Milovanović J (2007). Analiza svojstava semena i klijavaca različitih provenijencija brdske bukve [Analysis of seed and seedling traits of different provenances of beech]. Acta biologica iugoslavica - serija G: Acta herbologica 16 (1): 1527. [in Serbian]

Singh O, Sofi AH (2011). Clone variation of seed traits, germination and seedling growth in Dal- bergia sissoo Roxb. clonal seed orchard. Annals of Forest Research 54 (2): 139-149.

Sivakumar V, Gurudevsingh B, Anandalakshmi R, Warrier RR, Sekaran S, Tigabu M, Odén PC (2011). Culling phenotypically inferior trees in seed production area enhances seed and seedling quality of Acacia auriculiformis. Journal of Forestry Research 22 (1): 21-26. - doi: 10.1007/ s11676-011-0119-2

Skrøppa T (1994). Impacts of tree improvement on genetic structure and diversity of planted forests. Silva Fennica 28: 265-274. - doi: 10.14214 /sf.ag179

Skrøppa T, Kohmann K (1997). Adaptation to local conditions after one generation in Norway spruce. Forest Genetics 4: 171-177.

Skrøppa T, Tollefsrud MM, Sperisen C, Johnsen $O$ (2010). Rapid change in adaptive performance from one generation to the next in Picea abies - Central European trees in a Nordic environment. Tree Genetics and Genomes 6: 93-99. - doi: 10.1007/s11295-009-0231-z

St Clair JB, Adams WT (1993). Family composition of Douglas-fir nursery stock as influenced by seed characters, mortality, and culling practices. New Forests 7: 319-329.

St Clair JB, Howe GT (2007). Genetic maladaptation of coastal Douglas-fir seedlings to future climates. Global Change Biology 13: 1441-1454. doi: 10.1111/j.1365-2486.2007.01385.x

St Clair JB, Howe GT (2011). Strategies for conserving forest genetic resources in the face of climate change. Turkish Journal of Botany 35: 403-409.

Stihl EG, Persson B (1991). Provenance variation in early growth and development of Picea mariana (Mill) B.S.P. Studia Forestalia Suecica 187: 17.

Stoehr M, Webber J, Woods J (2004). Protocol for rating seed orchard seedlots in British Columbia: quantifying genetic gain and diversity. Forestry 77 (4): 297-303. - doi: 10.1093/fores try/77.4.297

Stoehr MU, El-Kassaby YA (1997). Levels of genetic diversity at different stages of the domestication cycle of interior spruce in British Columbia. Theoretical and Applied Genetics 94: 83-90. - doi: 10.1007/s001220050385

Sweet GB (1995). Seed orchards in development. Tree Physiology 15: 527-530. - doi: 10.1093/tree phys/15.7-8.527

Thomas BR, Macdonald SE, Hicks M, Adams DL, Hodgetts RB (1999). Effects of reforestation methods on genetic diversity of lodgepole pine: an assessment using microsatellite and randomly amplified polymorphic DNA markers. Theoretical and Applied Genetics 98: 793-801. doi: $10.1007 /$ soo1220051136

Thomas E, Jalonen R, Loo J, Boshier D, Gallo L, Cavers S, Bordács S, Smith P, Bozzano $M$ (2014). Genetic considerations in ecosystem restoration using native tree species. Forest Ecology and Management 333: 66-75. - doi: 10.1016/ j.foreco.2014.07.015

Thomsen KA, Kjaer ED (2002). Variation between single tree progenies of Fagus sylvatica in seed traits, and its implications for effective population numbers. Silvae Genetica 51 (5-6): 183-190. Thomson JR, Schultz RC (1995). Root system morphology of Quercus rubra L. planting stock and 3-year field performance in lowa. New 
Forests 9: 225-236. - doi: 10.1007/BFoo035489 Varelides C, Brofas G, Varelides Y (2001). Provenance variation in Pinus nigra at three sites in Northern Greece. Annals of Forest Science 58 (8): 893-900. - doi: 10.1051/forest:2001103 Williams MI, Dumroese RK (2013). Preparing for climate change: forestry and assisted migration. Journal of Forestry 111 (4): 287-297. - doi: 10.5849/jof.13-016

Woeste KE, Jacobs DF, McKenna JR (2011). Halfsib seed source and nursery sowing density affect black walnut (Juglans nigra) growth after five years. New Forests 41: 235-245. - doi: 10.1007/s11056-010-9224-x

Wright S (1931). Evolution in Mendelian populations. Genetics 16: 0097-0159.

Wu HXM, Yeh FC (1997). Genetic effect on biomass partition and breeding for tree architecture in Pinus contorta spp. latifolia from central Alberta. Forest Genetics 4: 123-131.

Yanchuk AD (2001). A quantitative framework for breeding and conservation of forest tree genetic resources in British Columbia. Canadian Journal of Forest Research 31: 566-576. - doi: 10.1139/x00-133

Yanchuk AD, Bishir J, Russell JH, Polsson KR (2006). Variation in volume production through clonal deployment: results from a simulation model to minimize risk for both a currently known and unknown future pest. Silvae Genetica 55 (1): 25-37. 